\title{
The outcomes of ultrasonic and laser therapy in case of temporomandibular disorders - an evidence based update
}

\author{
NEGUCIOIU Marius ${ }^{1}$, KUI Andreea ${ }^{1}$, MITARIU Mihai ${ }^{2}$, MANZIUC Manuela ${ }^{1}$, CONDOR Daniela $^{3}$, \\ MITARIU Loredana ${ }^{2}$, BUDURU Smaranda ${ }^{1}$
}

Editor: Mihail HOTETEU, Romanian Association of Balneology, hoteteu@yahoo.com

Reviewers: Constantin Munteanu and Gabriela Dogaru

*Corresponding author: KUI Andreea, E-mail: andreeakui@gmail.com;
${ }^{1}$ 1. "Iuliu Hatieganu" University of Medicine and Pharmacy, Department of Prosthodontics, Cluj Napoca, Romania
2."Lucian Balga" University, Department of Dental Medicine, Sibiu, Romania
3. "Iuliu Hatieganu" University of Medicine and Pharmacy, Department of Periodontics, Cluj Napoca, Romania

\begin{abstract}
Introduction. Temporomandibular disorders (TMDs) are considered multifactorial conditions, thereby with different therapy options, from occlusal equilibration, splint therapy, pharmacotherapy or physical therapy. Among the physical therapies, over the last years, laser therapy and ultrasound therapy have gained attention, as different experimental or clinical studies suggest their efficacy in case of TMDs. The aim of our literature review is to evaluate the available evidence on the effectiveness of laser and ultrasound therapy in the treatment of temporomandibular disorders. Material and method. A research of literature has been performed - articles published over the last 5 years (January 2016 until June 2021) were searched by introducing a combination of different terms, using the Pubmed, Scopus and Google Scholar databases. Results and discussions. A total number of 332 articles was found. For multiple publications regarding the same group of patients, the most recent studies were included. Initial analysis of titles and abstracts eliminated 232 articles, leaving 35 articles whose full text was examined. 20 articles met the inclusion criteria Conclusions. According to the findings of this literature update we can conclude that low level laser therapy, ultrasound therapy, and photobiomodulation may effectively reduce pain for patients suffering of muscular and joint TMDs. However, their effects appear to be only shortly maintained, and only for less complex cases. In addition, it was difficult to compare the studies included, as they do not offer an optimal usage (program, duration of sessions, or number of sessions) of each technique. In this context, we consider that further randomized clinical studies are necessarily to compare each physical technique as well as their synergic effect on the symptoms in case of temporomandibular disorders.
\end{abstract}

Keywords: temporomandibular disorders, low level laser therapy, ultrasound therapy, photobiomodulation, TMD, LLLT

\section{INTRODUCTION}

It is estimated that 1 in 5 adults in Europe, suffers from a dysfunction of their masticatory system, related to temporomandibular disorders (TMDs) $(1,2,3)$. According to the Diagnostic Criteria for TMD (DC/TMD) temporomandibular disorders are complaints involving the masticatory system, and refer to myalgia (pain situated in the masticatory muscles), arthralgia (pain situated in the temporomandibular joints), and/or functional complaints of the joints, such as limitation of mouth opening or joint sounds (clicking, crepitus) (4).

Muscle and joint pain represent the most frequent chief complaints of patients with TMDs, often being associated with muscle tension and fatigue, ranging from mild sensitivity to extreme discomfort, and frequently exacerbated by function of the muscles involved $(5,6)$.

As TMDs have a multifactorial etiology and variety in clinical presentations, treatment possibilities are also extensive and diverse, involving professionals from different areas. The most frequent therapies indicated are pharmacotherapy, occlusal equilibration and use of occlusal splints, as well as physical therapy, such as Low-Level Laser Therapy (LLLT), photobiomodulation,
Transcutaneous electrical nerve stimulation (TENS), ultrasound, massage or acupuncture $(6,7,8,9)$.

Over the last decade, the interest in using laser photobiomodulation in reducing TMD pain and obtaining anti-inflammatory effects has increased. According to Karu (2001) Low Level Laser treatment is a non-thermal therapy which can promote cell and tissue alterations caused by different types of metabolic activation (increased vascularization and the formation of fibroblasts) which determines an increase in the recovery process and/or tissue healing with non-invasive characteristics (10).

Laser therapy is known for several treatment properties, such as tissue repair, mediation of inflammatory processes, analgesia in acute and chronic pain, improving local microcirculation. In this context, the use of laser has increased in all areas of dentistry, especially in the management of TMDs, for obtaining analgesia and for reducing the inflammatory processes $(6,11)$.

Therapeutic ultrasound has also been commonly used by physiotherapists for muscle pain. Ultrasonic therapy has shown to have a thermal mechanism achieved by a continuous frequency $(100 \%$ duty cycle) and a non- 
thermal mechanism achieved by a pulsed frequency $(50 \%$ duty cycle) $(12,13)$.

Low Intensity Ultrasound (LIUS) therapy is used in case of musculoskeletal disorders, for its thermal and mechanical effects on the targeted tissues, increasing local metabolism, microcirculation, and also tissue regeneration along with extensibility of connective tissues (14). The mechanical energy released is transferred in the manner of acoustic compression waves, producing mechanical and thermal physiological changes in the targeted tissue. Thermal physiological changes refer to increasing the local tissue temperature, increasing the blood flow associated with the increasing of the flexibility and extensibility of tissue with diminished fluid viscosity (15). Those features make LIUS another common modality of treatment in case of TMDs.

In a clinical trial published in 2018 by De Souza Simao et al. (16) the ultrasonic and photobiomodulation technology combined showed good results in the treatment of hands and knee osteoarthritis, with pain relief and increase of joints (hand and knee) functional movements.

The two therapies mentioned above have been studied in case of temporomandibular disorders over the last years, either as unique option or in combination with other types of treatments. The aim of our literature review is to evaluate the available evidence on the effectiveness of laser and ultrasound therapy in the treatment of temporomandibular disorders, with regard to pain reduction, improvement of functional disability, and success rate.

\section{Materials and Methods}

\subsection{Search strategy}

In order to identify the studies involving the application of LLLT, photobiomodulation and LIUS in case of temporomandibular disorders, a literature search was performed. The databases PubMed, Scopus, Google Scholar were reviewed from January 2016 to July 2021.

The keywords "laser therapy", "low level laser therapy", "ultrasound therapy", "temporomandibular joint disorders", "facial pain" were used as terms or as a freetext in different combinations. In addition, we combined descriptors and terms using "AND" in the search process. The papers considered were only the ones using these descriptors.

Two authors have independently screened titles and abstracts for potential eligibility and the full texts. The data were extracted using a standardized data collection form, in order to record study design, methodological features, interventions, outcomes and missing outcome data.

\subsection{Inclusion criteria}

The inclusion criteria for the studies were as follows: studies investigating low level laser therapy, ultrasound therapy, studies reporting clinical series of patients
TMDs in treatment with either one of the methods or in combination, and clinical studies that included the follow-ups of the subjects included, systematic reviews and meta-analysis.

\subsection{Exclusion criteria}

Thesis, monographs, abstracts presented in conferences were excluded from the evaluation. In addition, studies that focused on intervention in animals and those not written in English or French were excluded from the evaluation process.

\section{Results}

The initial search revealed 332 articles. For multiple publications regarding the same group of patients, the most recent studies were included. Initial analysis of titles and abstracts eliminated 232 articles, leaving 35 articles whose full text was examined. A total of 20 articles met the inclusion criteria (Figure 1).

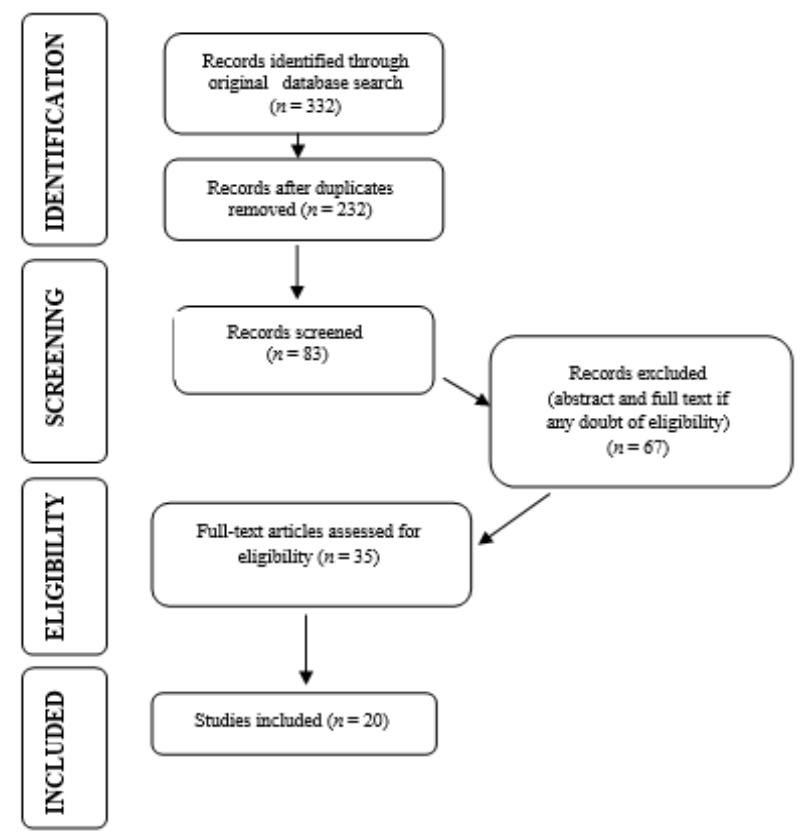

Figure 1 - PRISMA flow diagram for research stages

\section{Discussion}

The aim of this study was to evaluate the current literature on the outcomes of laser therapy and ultrasonic therapy for temporomandibular disorders (TMDs). Over the past five years the literature revealed a higher interest, compared to ultrasonic therapy, in the effectiveness of Low-Level Laser therapy (LLLT) and photodynamic therapy either as unique treatment or in combination with other types of physical therapies.

\subsection{Laser therapy in case of temporomandibular disorders}

A clinical trial published in 2016 by Cavalcanti et al. investigated the efficiency of LLLT on pain associated with TMD compared to physiotherapeutic and Drug Protocol (PDP therapy) on a sample of 60 female patients (17). LLL therapy was applied in five different points, 3 times per week, for 4 weeks, while PDP therapy involved 
a myorelaxant drug in association with an antiinflammatory drug and applications of hot packs, thrice a day and mouth exercise (twice a day). The results revealed that LLL therapy outcomes comparable with PDP therapy regarding pain reduction and improvement of functions for the patients included in the study.

A similar study, performed on 104 subjects with TMD, by Machado et al. (2016) investigated the effects of oral motor exercises (OMT) and laser therapy. The authors evaluated the two therapies either as unique treatments, or in combination. The results revealed that LLLT and OM-exercises combined were more effective in promoting TMD rehabilitation (decreasing the signs and symptoms and functional recovery) compared to LLLT alone. However complete OMT protocol was superior to the combined therapy (LLLT\& OM-exercises) (18).

A systematic review published in 2017 by Hosgor et al (19) investigated the efficiency of four types of minimally invasive treatments (LLLT, pharmacotherapy, inter-occlusal splint therapy and arthrocentesis therapy) in case of anterior displacement of the temporomandibular joint. The authors concluded, that based on their research, all four types of therapies investigated were successful in improving the clinical symptoms in patients with TMDs (table 1).

Borges et al. published a placebo-controlled clinical trial in 2018, investigating the effects of different photobiomodulation dosimetries on TMD. Their pilot study was performed on forty-four subjects and the results revealed a significant reduction of TMD pain and symptoms in all the photobiomodulation protocols used, but no effect over the temporomandibular joint mobility (20).

In a randomized clinical trial performed on 51 subjects, published in 2018, Brochado et al. compared the effectiveness of photobiomodulation and manual therapy, alone or combined, on pain intensity, mandibular movements, psychosocial aspects, and anxiety symptoms of TMDs. The findings of this research revealed that all protocols were able to decrease pain and improve mandibular movements, with the reduction of the negative effects of the psychosocial aspects and the anxiety symptoms. However, both therapies combined did not show an increase in the effect of both therapies alone (21).

Tuner at al. published a systematic review in 2019, investigating the applications of photobiomodulation in temporomandibular disorders. While their research revealed that the majority of studies included in the investigation showed that photobiomodulation is effective in reducing pain in case of TMDs, as well as to enhance mandibular functions, the heterogeneity of those studies did not allow for a standardization of photobiomodulation therapy (22). In addition, according to a literature review published by Karic et al.
(2019) photobiomodulation of stem cells with or without scaffolds could also be used indirectly or directly as modulation of degenerative changes of the temporomandibular joint disc (23).

Hanna et al. (2021) investigated the role of photobiomodulation therapy in modulating oxidative stress in case of temporomandibular disorders. The results of their systematic review and meta-analysis revealed that photobiomodulation of laser or LEDs, alone or combined, have fundamental and substantial effects on improving chronic pain and functionality in case of temporomandibular disorders (24).

A clinical trial published in 2019 by Abbasgholizadeh et al. aimed to evaluate the efficacy of three treatment options (splint therapy alone, ultrasound guided arthrocentesis and splint therapy, splint therapy + LLLT) and to compare their outcomes in patients with painful unilateral disc displacement. The results showed that all methods were effective on pain and functional jaw movements in treating temporomandibular disorders; however, when the groups were compared, the application of LLLT did not make a significant contribution to pain and functional jaw movements (25).

\subsection{Ultrasonic therapy in case of temporomandibular} disorders

Rai et al. (2016) compared the efficiency of ultrasound therapy and transcutaneous electrical nerve stimulation (TENS), in the management of myofascial pain of TMD (table 1). The results of the clinical trial (performed on 90 subjects) showed better results with a statistically significant difference when compared with TENS therapy, based on the basis of VAS score of muscle pain (26). A similar study, published in 2018 by Kirupa et al., aimed to investigate the effectiveness of ultrasound and TENS therapies in case of temporomandibular disorders. Statistical analysis revealed that ultrasound therapy was more effective in reducing pain than TENS (27).

In a clinical trial published by Hussain et al. (2018) the immediate effect of continuous ultrasound and sham ultrasound in case of bilateral masseter myalgia has been investigated. The measures used to evaluate the results included pre- and post-self-reported pain intensity recorded on a verbal rating scale (VRS), pressure pain thresholds for the masseter (PPT-M) and temporalis (PPT-T) muscles, and intraoral temperature for the masseter muscle. The authors concluded that therapeutic ultrasound (with a setting of $0.4 \mathrm{w} / \mathrm{cm} 2$ with $100 \%$ continuous duty cycle significantly) might be more effective for bilateral master myalgia (28).

Handa et al. (2018) evaluated the efficacy of ultrasound massage therapy as an adjuvant pain control modality in TMDs, in a pilot study performed on 10 subjects. All the patients were treated with US, once a week for 4 weeks for $8 \mathrm{~min}$ and pain intensity was evaluated using visual analog scale, in every session. The authors concluded 
that ultrasound massage therapy appeared to be useful in relieving pain and improves subsequent mouth opening, and hence can be considered as a valuable physiotherapy method (29).

A study performed on 50 subjects, regarding a comparative efficiency of analgesic gel phonophoresis and ultrasound therapy, was performed by Ramakrishnan et al. (2019). The results suggested that both therapies plain ultrasound and phonophoresis with aceclofenac gel are effective in the management of temporomandibular disorders (30).

Ba et. al (2021) published a clinical trial performed on 160 patients with TMD, investigating the effects of ultrasound therapy on pain. The results indicated that ultrasound therapy as effective to treat TMDs symptoms (pain reduction and improvement of jaw functions), and the effects were persistent in a follow-up period, with less than 3\% recurrence rate after ultrasound therapy (31).

\subsection{Combined therapies in case of temporomandibular disorders}

El-sharkawy and Ahmad (2018) investigated the effect of low-level laser therapy combined with conventional physiotherapy on pain and quality of life in patients suffering from temporomandibular disorders. The study was performed on 60 subjects, divided in two groups (study and control group); for both groups, physiotherapy consisted in hot pack applications, exercise program and ultrasound application, while for the study group LLL therapy was also performed (32).

In a randomized comparative study published by Jain et al., the efficacy of conventional therapy over therapeutic ultrasound \& conventional therapy was tested in the management of myofascial pain. 20 patients were enrolled, and each of them received conventional therapy (anti-inflammatory drugs, local myorelaxant gel and local hot packs application), while the subjects in the study group received also ultrasound therapy (33). The results revealed a significant pain reduction in the patients who received ultrasound therapy - a decrease in pain over temporomandibular joint area, while tenderness over masseter and lateral pterygoid improved, as well as the mouth opening.

A literature review published in 2018 by Abouelhuda et al. investigated the validity and outcomes of non-invasive and surgical therapies in case of temporomandibular disorders (TMDs). Regarding physical therapy the authors mentioned Low level Laser Therapy, Ultrasound therapy and TENS as the main possibilities, as well as their important part in the protocol and staging of treatment in case of TMDs (34).

The efficiency of ultrasound heat therapy compared to LLLT was investigated by Khairnar et al. in a study published in 2019. The research was performed on fortytwo patients with TMD, and divided into two study groups: group A received anti-inflammatory drugs and LLL therapy, while group B received same antiinflammatory drugs and ultrasound therapy. Statistical analysis of the results revealed that LLLT was superior that ultrasound in pain reduction; however, the authors mentioned in addition that this therapy is effective in cases with no underlying bony pathology (35).

A clinical study published by Panhóca et al. in 2019 aimed to analyze the oral health-related quality of life (OHRQoL) of patients with temporomandibular disorders (TMDs) who were treated simultaneously with ultrasound (US) and photobiomodulation therapy (PBMT). 13 patients were included in this study, all diagnosed with temporomandibular disorder. The subjects were treated with a prototype equipment consisting of US and PBMT in the same system. The treatment was applied to the left and right sides of the face, in the masseter muscle, anterior temporalis muscle, and temporomandibular joint, two sessions per week for a total of eight sessions. The authors concluded that synergistic treatment (ultrasound + photobiomodulation) improved the OHRQoL of patients with TMDs, and its beneficial effects persisted 1 month after termination of treatment (36). Their study was preceded by a case presentation published in 2018, in which a 27 years old female patient was treated with a combination of ultrasound and laser therapy with an analgesic effect and improvement of the patient's quality of life (37).

Elgohary et al. published a clinical study in 2018 which aimed to compare the effects of low intensity ultrasound (LIUS), traditional exercise therapy (TET), low level laser therapy (LLLT) and TET on temporomandibular joint (TMJ) pain and trismus following recovery from head and neck cancer (HNC). Performed on sixty participants who had experienced head and neck cancer, the research comprised in three groups, as follows: group A received LIUS and TET; group B received LLLT and TET; while group $\mathrm{C}$ received TET. The authors concluded that LIUS and TET were more effective than LLLT and/or TET in reducing TMJ pain and trismus following HNC (38).

\section{Conclusion:}

According to the findings of this literature update we can conclude that low level laser therapy, ultrasound therapy, and photobiomodulation may effectively reduce pain for patients suffering of muscular and joint TMDs. However, their effects appear to be only shortly maintained, and only for less complex cases. Furthermore, LLLT may also improve oro-facial functions, reducing muscle hyperactivity. This evidence-based review also highlights the need for better-designed clinical trials with larger sample sizes, in order to evaluate the efficacy of LLLT, photobiomodulation and ultrasound therapy on improving the signs and symptoms of TMDs. 
Table 1. General information about the clinical studies included in the research

\begin{tabular}{|c|c|c|c|}
\hline Author/ year & $\begin{array}{l}\text { Type of study } \\
\text { /no. of subjects }\end{array}$ & Treatment & Outcomes \\
\hline $\begin{array}{l}\text { Cavalcanti et al } \\
(2016)\end{array}$ & $\begin{array}{l}\text { Clinical trial/60 } \\
\text { female subjects }\end{array}$ & $\begin{array}{l}\text { Group } 1-\text { LLL }(780 \mathrm{~nm} \text { laser, dose of } 35.0 \\
\mathrm{J} / \mathrm{cm} 2 \text {, for } 20 \mathrm{sec} \text {, thrice a week, for } 4 \text { weeks); } \\
\text { Group 2-PDP (hot packs thrice a day, } \\
\text { myorelaxing and anti-inflammatory drug } \\
\text { administration); } \\
\text { Group 3-Placebo }\end{array}$ & $\begin{array}{l}\text { Compared to PDP, LLL treatment was } \\
\text { effective to control pain associated with } \\
\text { TMD }\end{array}$ \\
\hline $\begin{array}{l}\text { Machado et al. } \\
\text { (2016) }\end{array}$ & $\begin{array}{l}\text { Clinical trial/102 } \\
\text { subjects }\end{array}$ & $\begin{array}{l}\text { Group } 1 \text { - LLLT + orofacial myofunctional } \\
\text { exercises; } \\
\text { Group } 2 \text { - orofacial myofunctional therapy- } \\
\text { OMT; Group } 3 \text { - LLLT placebo }+ \text { orofacial } \\
\text { myofunctional exercises; } \\
\text { Group } 4 \text { - LLLT (AsGaAl; } 780-\mathrm{nm} \text { wave- } \\
\text { length; average power of } 60 \mathrm{~mW}, 40 \mathrm{~s} \text {, and } \\
60 \pm 1.0 \mathrm{~J} / \mathrm{cm}^{2} \text { ) }\end{array}$ & $\begin{array}{l}\text { LLLT combined with OM-exercises } \\
\text { was more effective in promoting TMD } \\
\text { rehabilitation than LLLT alone was. } \\
\text { Similar treatment results were verified } \\
\text { with the OMT protocol }\end{array}$ \\
\hline $\begin{array}{l}\text { Hosgor et al. } \\
\text { (2017) }\end{array}$ & $\begin{array}{l}\text { Clinical trial/ } 40 \\
\text { subjects with } \\
\text { unilateral TMD }\end{array}$ & $\begin{array}{l}\text { Group } 1-\text { splint therapy; Group } 2- \\
\text { arthrocentesis; Group } 3-\text { medical therapy; Group } \\
4-\text { low-level laser therapy }((500 \mathrm{~mW} \text { output } \\
\text { power for } 180 \mathrm{~s} \text { and } 321 \mathrm{~J} / \mathrm{cm} 2 \text { energy density/ } \\
\text { 3-min sessions, three times a week for } 4 \text { weeks })\end{array}$ & $\begin{array}{l}\text { All non-invasive treatment methods } \\
\text { used were successful in improving the } \\
\text { clinical symptoms in patients with TMD }\end{array}$ \\
\hline $\begin{array}{l}\text { Borges et al } \\
(2018)\end{array}$ & $\begin{array}{l}\text { Randomized } \\
\text { double-blind } \\
\text { clinical trial/44 } \\
\text { subjects }\end{array}$ & $\begin{array}{l}\text { Different dosimetries of photobiomodulation: } \\
\text { group } 1-8 \mathrm{~J} / \mathrm{cm} 2(\mathrm{n}=11) \text {, group } 2-60 \mathrm{~J} / \mathrm{cm} 2(\mathrm{n} \\
=11) \text {, group } 3-105 \mathrm{~J} / \mathrm{cm} 2(\mathrm{n}=11) \text {, and control } \\
\text { group }(\mathrm{n}=11)\end{array}$ & $\begin{array}{l}\text { All dosimetries significantly decreased } \\
\text { pain }(\mathrm{p}<0.05) \text {. Only the doses of } 8 \\
\mathrm{~J} / \mathrm{cm} 2 \text { were effective regarding maximal } \\
\text { opening and protrusion of the mandible }\end{array}$ \\
\hline $\begin{array}{l}\text { Brochado et al. } \\
\text { (2018) }\end{array}$ & $\begin{array}{l}\text { Randomized } \\
\text { clinical trial/51 } \\
\text { subjects }\end{array}$ & $\begin{array}{l}\text { Group } 1(\mathrm{n}=18)-\text { photobiomodulation with } 808 \\
\mathrm{~nm}, 100 \mathrm{~mW}, 13.3 \mathrm{~J} / \mathrm{cm} 2 \\
\text {, and } 4 \mathrm{~J} \text { per point; group } 2(\mathrm{n}=16)-\text { manual } \\
\text { therapy for } 21 \text { minutes each session on } \\
\text { masticatory muscles and temporomandibular } \\
\text { joint TMJ; combined therapy }(\mathrm{n}=17)\end{array}$ & $\begin{array}{l}\text { All protocols studied were able to } \\
\text { promote pain relief, improve } \\
\text { mandibular function, and reduce the } \\
\text { negative psychosocial aspects and levels } \\
\text { of anxiety in TMD patients; } \\
\text { The combined therapy did not promote } \\
\text { an increase in the effectiveness of both } \\
\text { therapies alone }\end{array}$ \\
\hline $\begin{array}{l}\text { Abbasgholizade } \\
\text { h et al. (2019) }\end{array}$ & $\begin{array}{lr}\text { Clinical } & \text { Trial } / 45 \\
\text { subjects } & \text { with } \\
\text { unilateral } & \text { TMD }\end{array}$ & $\begin{array}{l}3 \text { groups: group 1- splint therapy; group } 2- \\
\text { splint therapy with ultrasound-guided } \\
\text { arthrocentesis; group } 3 \text { - splint therapy with low- } \\
\text { level laser therapy (Nd: YAG laser system at an } \\
\text { output power of } 500 \mathrm{~mW}, 321 \mathrm{~J} / \mathrm{cm} 2 \text { energy } \\
\text { intensity, and } 1064 \mathrm{~nm} \text { wavelength. } \\
\text { Biostimulation for } 1 \text { minute to each painful } \\
\text { point, three times weekly for } 4 \text { weeks) }\end{array}$ & $\begin{array}{l}\text { The application of LLLT did not make a } \\
\text { significant contribution to pain and } \\
\text { functional jaw movements; US-guided } \\
\text { arthrocentesis provided a faster } \\
\text { improvement in the treatment of painful } \\
\text { TMJ }\end{array}$ \\
\hline Rai et al. (2016) & $\begin{array}{l}\text { Clinical trial/ } 90 \\
\text { subjects }\end{array}$ & $\begin{array}{l}3 \text { groups: group 1- healthy control patients; } \\
\text { group 2 - ultrasound therapy; group } 3 \text { - TENS } \\
\text { therapy }\end{array}$ & $\begin{array}{l}\text { Ultrasound therapy appeared to be } \\
\text { subjectively better, in the context of } \\
\text { visual analogue scale score of massage } \\
\text { impression, muscle pain, and } \\
\text { impediment to daily life after treatment }\end{array}$ \\
\hline $\begin{array}{l}\text { Hussain et al. } \\
(2018)\end{array}$ & $\begin{array}{l}\text { Clinical trial } / 20 \\
\text { female subjects }\end{array}$ & $\begin{array}{l}2 \text { groups: group } 1-\text { ultrasound therapy }(0.4 \\
\text { w/cm } 2 \text { with } 100 \% \text { duty cycle for } 5 \text { minutes); } \\
\text { group } 2-\text { sham ultrasound therapy }\end{array}$ & $\begin{array}{l}\text { Therapeutic ultrasound produced an } \\
\text { immediate increase in pressure pain } \\
\text { thresholds for the masseter and intraoral } \\
\text { temperature compared to sham } \\
\text { ultrasound }\end{array}$ \\
\hline
\end{tabular}




\begin{tabular}{|c|c|c|c|}
\hline $\begin{array}{l}\text { Handa et al. } \\
(2018)\end{array}$ & $\begin{array}{l}\text { Clinical trial/ } 10 \\
\text { subjects }\end{array}$ & $\begin{array}{l}\text { Ultrasound massage therapy (frequency of } 1 \\
\mathrm{MHz} \text { and pulse setting at } 1: 1 \text { for } 8 \mathrm{~min} \text { each } \\
\text { session, once a week for } 4 \text { comparative weeks.) }\end{array}$ & $\begin{array}{l}\text { The method was useful in relieving pain } \\
\text { and in improving subsequent mouth } \\
\text { opening }\end{array}$ \\
\hline $\begin{array}{l}\text { Ramakrishnan } \\
\text { et al. (2019) }\end{array}$ & $\begin{array}{l}\text { Clinical trial/ } 50 \\
\text { subjects }\end{array}$ & $\begin{array}{l}2 \text { groups: group A - plain ultrasound and group } \\
\text { B - phonophoresis with aceclofenac gel. }\end{array}$ & $\begin{array}{l}\text { Both methods were effective in the } \\
\text { management of temporomandibular } \\
\text { disorders. }\end{array}$ \\
\hline Ba et. al (2021) & $\begin{array}{l}\text { Clinical trial/ } \\
160 \text { subjects }\end{array}$ & $\begin{array}{l}2 \text { groups: group } 1-\text { ultrasound therapy (output of } \\
45 \mathrm{~W} \text { and frequency of } 800 \mathrm{kHz} / \text { three } 5 \text {-minute } \\
\text { blasts with a } 2 \text {-minute interval between the } \\
\text { blasts, once a day for } 5 \text { days in a week, } 2 \text { weeks); } \\
\text { group } 2 \text { - control group (no therapy) }\end{array}$ & $\begin{array}{l}\text { US therapy significantly reduced pain, } \\
\text { and improved the functionality of TMJ } \\
\text { and mouth opening limit }\end{array}$ \\
\hline $\begin{array}{l}\text { El-sharkawy } \\
\text { and Ahmad } \\
\text { (2018) }\end{array}$ & $\begin{array}{l}\text { Clinical trial/ } 60 \\
\text { subjects }\end{array}$ & $\begin{array}{l}2 \text { groups: study group - active and stretching } \\
\text { exercises for mandibular muscles with } \\
\text { ultrasound and LLLT application; control group } \\
\text { - conventional physiotherapy only; }\end{array}$ & $\begin{array}{l}\text { The combination of conventional } \\
\text { therapy with LLLT was more effective } \\
\text { in pain relief and improvement of the } \\
\text { quality of life than the conventional } \\
\text { therapy alone }\end{array}$ \\
\hline $\begin{array}{l}\text { Jain et al. } \\
(2020)\end{array}$ & $\begin{array}{l}\text { Clinical trial/ } 20 \\
\text { subjects }\end{array}$ & $\begin{array}{l}2 \text { groups: group } 1-\text { conventional therapy and } \\
\text { therapeutic ultrasound (frequency of } 1 \mathrm{MHz} \text { and } \\
\text { continuous setting at } 1: 1 \text { for } 6 \text { min each session); } \\
\text { group } 2-\text { conventional therapy only }\end{array}$ & $\begin{array}{l}\text { US massage therapy was beneficial in } \\
\text { relieving pain and for improving } \\
\text { subsequent mouth opening }\end{array}$ \\
\hline $\begin{array}{l}\text { Khairnar et al. } \\
\text { (2019) }\end{array}$ & \begin{tabular}{|l|} 
Clinical trial/ 42 \\
patients
\end{tabular} & $\begin{array}{l}3 \text { groups: group } 1-\text { pharmacotherapy; group } 2- \\
\text { LLLT (660-nm laser light was applied directly } \\
\text { over } \\
\text { the TMJ region for three minutes at } 2.2 \text { Joules } \\
\text { per minute); group } 3-\text { ultrasound therapy }(1.8 \\
\text { w/cm } 2 \text { for } 10 \text { min per session) }\end{array}$ & $\begin{array}{l}\text { LLLT has superior results in mouth } \\
\text { opening compared with ultrasound } \\
\text { therapy }\end{array}$ \\
\hline $\begin{array}{l}\text { Panhóca et al. } \\
\text { (2019) }\end{array}$ & $\begin{array}{l}\text { Clinical study/ } \\
13 \text { patients }\end{array}$ & $\begin{array}{l}\text { All subjects treated with a combination therapy: } \\
\text { ultrasound (US) and photobiomodulation (laser } \\
\text { diode at } 808 \mathrm{~nm} \text {, power } 100 \mathrm{~mW} \text {, and spot area } \\
1.76 \mathrm{~mm} 2 \text {; and US with frequency of } 1.0 \mathrm{MHz} \text {, } \\
\text { intensity } 1 \mathrm{~W} / \mathrm{cm} 2,50 \% \text { pulsed work cycle, and } \\
\text { effective radiation area of } 1.6 \mathrm{~cm} 2 \text {.) }\end{array}$ & $\begin{array}{l}\text { Combined treatment, US + PBMT, } \\
\text { improved the subjects' quality of life, } \\
\text { and the effects persisted } 1 \text { month after } \\
\text { termination of treatment. }\end{array}$ \\
\hline $\begin{array}{l}\text { Elgohary et al. } \\
(2018)\end{array}$ & 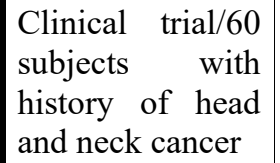 & $\begin{array}{l}3 \text { groups: group A received ultrasound and } \\
\text { traditional exercise therapy; group B received } \\
\text { LLLT and traditional exercise therapy; while } \\
\text { group C received traditional exercise therapy. }\end{array}$ & $\begin{array}{l}\text { The ultrasound and traditional exercise } \\
\text { therapy were more effective than LLLT } \\
\text { and/or traditional exercise therapy in } \\
\text { reducing TMJ pain and trismus }\end{array}$ \\
\hline
\end{tabular}




\section{Author contributions}

Conceptualization, A.K. D.C; methodology, A.K.and S.B..; software, M.N. and M.M; validation, M.M and M.L..; resources, M.N.; writing-original draft preparation, A.K.; writing - review and editing, M.N and M.M.; visualization, M.N. and S.B; supervision, S.B.; project administration, S.B.

\section{Conflicts of Interest}

The authors declare that they have no potential conflicts of interest with respect to the research, authorship, and/or publication of this article.

\section{References}

1. Carmeli E, Sheklow SL, Bloomenfeld I. Comparative study of repositioning splint therapy and passive manual range of motion techniques for anterior displaced temporomandibular discs with unstable excursive reduction. Physiotherapy. 2001;87(1):26-36. doi:10.1016/S0031-9406(05)61189-3.

2. Graciele Carrasco T, Oliveira Mazzetto M, Galli Mazzetto R, Mestriner W. Low Intensity Laser Therapy in Temporomandibular Disorder: a Phase II Double-Blind Study. $\quad$ Cranio ${ }^{\circledR}$ 2008;26(4):274-281. doi:10.1179/crn.2008.037

3. van der Meer HA, Calixtre LB, Engelbert RHH, Visscher CM, Nijhuis - van der Sanden MW, Speksnijder CM. Effects of physical therapy for temporomandibular disorders on headache pain intensity: A systematic review. Musculoskelet Sci Pract. 2020;50:102277. doi:10.1016/j.msksp.2020.102277

4. Cooper BC, Kleinberg I. Establishment of a temporomandibular physiological state with neuromuscular orthosis treatment affects reduction of TMD symptoms in 313 patients. Cranio ${ }^{\circledR}$. 2008;26(2).

5. Mazzetto MO, Hotta TH, Pizzo RCA. Measurements of jaw movements and TMJ pain intensity in patients treated with GaAlAs laser. Braz Dent J. 2010;21:356-60.

6. Maia ML de M, Bonjardim LR, Quintans J de SS, Ribeiro MAG, Maia LGM, Conti PCR. Effect of low-level laser therapy on pain levels in patients with temporomandibular disorders: A systematic review. J Appl Oral Sci. 2012;20(6):594-602.

7. Carvalho CM, Lacerda JA, Santos Neto FP, Cangussu MC, Marques AM, Pinheiro ALB. Wavelength effect in temporomandibular joint pain: a clinical experience. Lasers Med Sci. 2010;25:229-32.

8. Kato MT, Kogawa eM, Santos CN, Conti PCR. TeNS and low- level laser therapy in the management of temporomandibular disorders. J Appl Oral Sci. 2006;14:130-5.

9. Mazzetto MO, Hotta TH, Pizzo RC. Measurements of jaw movements and TMJ pain intensity in patients treated with GaAlAs laser. Braz Dent J. 2010;21(4):356-60. doi: 10.1590/s0103-64402010000400012.

10. Karu TI, Afanasyeva NI, Kolyakov SF, Pyatibrat LV, Welser L. Changes in absorbance of monolayer of living cells induced by laser irradiation at 633,670 , and $820 \mathrm{~nm}$. Ieee J Sel Top Quantum electron. 2001;7:982-8.

11. Pinheiro ALB, Cavalcanti eT, Pinheiro TI, Alves MJ Miranda eR, Quevedo AS, et al. Low-level laser therapy is an important tool to treat disorders of the maxillofacial region. J Clin Laser Med Surg. 1998;16:223-6.

12. Ter Haar G. Basic physics of therapeutic ultrasouns. Physiotherapy 1978;64:100-103.

13. Hsieh YL. Reduction in induced pain by ultrasound may be caused by altered expression of spinal neuronal nitric ox- ide synthase-producing neurons. Arch Phys Med Rehabil 2005;86:1311-1317.

14. van der Windt DAWM, van der Heijden GJMG, van den Berg SGM, Ter Riet G, de Winter AF, Bouter LM. Ultrasound therapy for musculoskeletal disorders: a 
systematic review. Pain. 1999 Jun;81(3):257-271. doi: 10.1016/S0304-3959(99)00016-0.

15. Elgohary HM, Eladl HM, Soliman AH, Soliman ES. Effects of Ultrasound, Laser and Exercises on Temporomandibular Joint Pain and Trismus Following Head and Neck Cancer. Ann Rehabil Med. 2018;42(6):846-853.doi: 0.5535/arm.2018.42.6.846.

16. Simao ML DS, AC F, RL C, AL Z, H C, Junior AE de A, et al. Sinergic Effect of Therapeutic Ultrasound and LowLevel Laser Therapy in the Treatment of Hands and Knees Ostheoarthritis. J Arthritis. 2018;07(06):1-4.

17. Cavalcanti MFXB, Silva UH, Leal-Junior ECP, LopesMartins RAB, Marcos RL, Pallotta RC, et al. Comparative study of the physiotherapeutic and drug protocol and low-level laser irradiation in the treatment of pain associated with temporomandibular dysfunction. Photomed Laser Surg. 2016;34(12):652-6.

18. Machado BCZ, Mazzetto MO, Da Silva MAMR, de Felício CM. Effects of oral motor exercises and laser therapy on chronic temporomandibular disorders: a randomized study with follow-up. Lasers Med Sci 2016;31(5):945-54. doi:10.1007/s10103-016-1935-6

19. Hosgor H, Bas B, Celenk C. A comparison of the outcomes of four minimally invasive treatment methods for anterior disc displacement of the temporomandibular joint. Int J Oral Maxillofac Surg 2017;46(11):1403-10. doi:10.1016/j.ijom.2017.05.010

20. Borges RMM, Cardoso DS, Flores BC, da Luz RD, Machado CR, Cerveira GP, et al. Effects of different photobiomodulation dosimetries on temporomandibular dysfunction: a randomized, double-blind, placebocontrolled clinical trial. Lasers Med Sci. 2018;33(9):1859-66.

21. Brochado FT, Jesus LH de, Carrard VC, Freddo AL, Chaves KD, Martins MD. Comparative effectiveness of photobiomodulation and manual therapy alone or combined in TMD patients: a randomized clinical trial. Braz Oral Res. 2018;32:e50.

22. Tunér J, Hosseinpour S, Fekrazad R. Photobiomodulation in Temporomandibular Disorders. Photobiomodulation, Photomedicine, Laser Surg. 2019;37(12):826-36.

23. Karic V, Chandran R, Abrahamse H. Photobiomodulation and Stem Cell Therapy for Temporomandibular Joint Disc Disorders. Photobiomodulation, Photomedicine, Laser Surg. 2020;38(7):398-408.

24. Hanna R, Dalvi S, Bensadoun J. Role of Photobiomodulation Therapy in Modulating Oxidative Stress in Temporomandibular Disorders . A Systematic Review and Meta-Analysis of Human Randomised Controlled Trials. 2021.

25. Abbasgholizadeh ZS, Evren B, Ozkan Y. Evaluation of the efficacy of different treatment modalities for painful temporomandibular disorders. Int J Oral Maxillofac Surg 2020;49(5):628-35. doi:10.1016/j.ijom.2019.08.010

26. Rai S, Ranjan V, Misra D, Panjwani S. - Management of myofascial pain by therapeutic ultrasound and transcutaneous electrical nerve stimulation: A comparative study. Eur J Dent 2016;10:46-53.

27. Kirupa K, Divya Mary SM, Vaishnavi G, Nithya Nisha R, Rennie Mercy J, Jaiganesh G. A comparative study of ultrasound therapy and transcutaneous electrical nerve stimulation in reducing pain for temporomandibular joint disorder. Drug Invent Today. 2019;12(3):515-7.

28. Hussain H, Crow H, Gonzalez Y, McCall W. Immediate Effect of Continuous Ultrasound vs Sham Ultrasound for Bilateral Masseter Myalgia: A Double-Blinded Trial. J Oral Facial Pain Headache. 2018;32(3):304-8.

29. Handa R, Sunil M K, Gupta C, Raina A, Khan T, Gulzar A. Efficacy of ultrasound massage therapy as an adjuvant pain control modality in TMDs: A clinical study.J Indian Acad Oral Med Radiol 2018;30:107-109.

30. Ramakrishnan S, Aswath N. Comparative efficacy of analgesic gel phonophoresis and ultrasound in the treatment of temporomandibular joint disorders. Indian $\mathrm{J}$ Dent Res. 2019;30(4):512-5.

31. Ba S, Zhou P, Yu M. Ultrasound is Effective to Treat Temporomandibular Joint Disorder. J Pain Res. 2021; Volume 14:1667-73.

32. El-sharkawy A, Ahmad R. Effect of low-level LASER therapy combined with conventional physiotherapy on pain and quality of life in patients with Myofascial pain dysfunction syndrome. Egypt Dent J. 2018;64(4):311123.

33. Jain R, Mhapuskar A, Prasad Hiremutt DR, Kalyanpur K, Badani H, Koppala RH. Efficacy of ultrasound massage therapy in myofascial pain - A randomized single-blind clinical study. Eur J Mol Clin Med 2020;7(5 CC-Oral Health):13-25. doi:10.1002/central/CN-02212665/full

34. Abouelhuda AM, khalifa AK, Kim YK, Hegazy SA. Noninvasive different modalities of treatment for temporomandibular disorders: Review of literature. J Korean Assoc Oral Maxillofac Surg. 2018;44(2):43-51.

35. Khairnar S, Bhate K, S.N. SK, Kshirsagar K, Jagtap B, Kakodkar P. Comparative evaluation of low-level laser therapy and ultrasound heat therapy in reducing temporomandibular joint disorder pain. J Dent Anesth Pain Med. 2019;19(5):289.

36. Panhóca VH, Bagnato VS, Alves N, Paolillo FR, Deana NF. Increased Oral Health-Related Quality of Life Postsynergistic Treatment with Ultrasound and Photobiomodulation Therapy in Patients with Temporomandibular Disorders. Photobiomodulation, Photomedicine, Laser Surg. 2019;37(11):694-9.

37. Panhóca VH, Lopes LB, Paolillo FR, Bagnato VS. Treatment of Temporomandibular Disorder Using Synergistic Laser and Ultrasound Application. Ohdm. 2018;17(2):1-5.

38. Elgohary HM, Eladl HM, Soliman AH, Soliman ES. Effects of Ultrasound, Laser and Exercises on Temporomandibular Joint Pain and Trismus Following Head and Neck Cancer. Ann Rehabil Med. 2018;42(6):846-853. doi:10.5535/arm.2018.42.6.846. 